\title{
PELAYANAN ADMINISTRATIF BAGI MASYARAKAT DI KECAMATAN GALANG KOTA BATAM
}

\author{
Karol Teovani Lodan; Bobby Mandala Putra \\ Administrasi Negara Universitas Putera Batam \\ karol@puterabatam.ac.id / bobby@puterabatam.ac.id
}

\begin{abstract}
This study aims to analyze administrative service efforts provided and constraints faced by Galang District. The results of the study indicate that efforts in administrative services include: submitting application files through (entrusted) to the local kelurahan, file storage through providers of pompong, joint ceremonies and meetings at the beginning of each month (first and second week), providing official housing around sub-district complexes, files can be submitted at the official residence of the employee outside of service hours and socialization has been carried out to improve understanding of service information. This condition shows that there is an interaction between the community and the apparatus in finding a shared solution related to services that can benefit. The obstacles faced include: first, inadequate internet network and only re-installed at the beginning of 2018. Secondly, electricity which still relies on generators and is only affordable by PLN at the end of 2018. Thirdly, damaged E-KTP recording devices so the community must move to the nearest sub-district to do the recording. Fourth, the lack of public understanding of the service system concerning the terms and procedures that must be passed so that the assumption arises that the service is difficult. This has an impact on the comfort and speed of service. The low level of public understanding of the service system is the responsibility of the apparatus to translate it so that it is easily understood.
\end{abstract}

Keywords: Service, Administrative Service, District.

\section{PENDAHULUAN}

Pemberlakuan otonomi daerah telah memberikan ruang akan kehadiran pemerintah daerah yang lebih dekat dengan masyarakat. Tanggungjawab utama kehadiran pemerintah daerah adalah penyelenggaraan pelayanan publik. Pemerintah daerah lebih mudah dan lebih dekat dalam melayani serta memahami kebutuhan masyarakat. Pemberian pelayanan yang berkualitas kepada masyarakat tentu akan dapat menciptakan kesejahteraan masyarakat yang merupakan tujuan dari negara. Pengertian tentang pelayanan publik telah pula diatur dalam UndangUndang Nomor 25 Tahun 2009 Tentang Pelayanan Publik, yaitu kegiatan atau rangkaian kegiatan dalam rangka pemenuhan kebutuhan pelayanan sesuai dengan peraturan perundang-undangan bagi setiap warga negara dan penduduk atas barang, jasa, dan/atau pelayanan administratif yang disediakan oleh 
penyelenggara pelayanan publik. Sedangkan penyelenggara pelayanan publik merujuk pada pemahaman yang mencakup setiap institusi penyelenggara negara, korporasi, lembaga independen yang dibentuk berdasarkan undang-undang untuk kegiatan pelayanan publik, dan badan hukum lain yang dibentuk semata-mata untuk kegiatan pelayanan publik. Dalam konteks ini, dapat dipahami bahwa pemerintah daerah termasuk dalam salah satu yang menyelenggarakan pelayanan publik.

Pelayanan publik merupakan sebuah kebutuhan bagi masyarakat yang bersifat dinamis. Hal ini berkaitan dengan semakin berkembang dan kompleksnya tuntutan masyarakat sehingga pelayanan publik terus mengikuti situasi tersebut. Misalnya, penggunaan KTP elektronik yang saat ini diwajibkan bagi seluruh masyarakat untuk meningkatkan efisiensi dan efektifitas dalam pengurusan berbagai layanan seperti perbankan, kepolisian, kesehatan dan lain-lain. Pelayanan publik merupakan sebuah ruang antara masyarakat dan pemerintah daerah untuk berdialog dalam merumuskan dan merealisasikan berbagai program layanan. Dengan demikian, pelayanan publik tidak hanya urusan pemerintah saja melainkan masyarakat. Pandangan baru yang terjadi saat ini dalam proses penyelengaraan pelayanan publik yang lebih transparan dan demokratis adalah yang berfokus pada penerima layanan. Artinya berbagai upaya pemerintah daerah dalam penyelenggaraan pelayanan haruslah disesuaikan dengan tuntutan dan harapan masyarakat sesuai dengan hak dan kewajiban sebagai warga negara.

Pada konteks pelayanan kepada masyarakat, pemerintah daerah dibantu oleh perangkat daerah. Salah satu perangkat daerah yang memiliki tugas dan tanggungjawab dalam merealisasikan pelayanan kepada masyarakat adalah kecamatan. Sebagaimana diketahui, bahwa sejarah kecamatan sebagai kepala wilayah saat ini atau semenjak pemberlakuan otonomi daerah telah berubah menjadi perangkat daerah. Dalam Peraturan Pemerintah Nomor 19 Tahun 2008 Tentang Kecamatan, disebutkan bahwa kecamatan atau sebutan lain adalah wilayah kerja Camat sebagai Perangkat daerah kabupaten/kota. Selanjutnya disebutkan juga bahwa Camat atau sebutan lain adalah pemimpin dan koordinator penyelenggaraan pemerintahan di wilayah kerja kecamatan yang dalam 
pelaksanaan tugasnya memperoleh pelimpahan kewenangan pemerintahan dari Bupati/Walikota untuk menangani sebagian urusan otonomi daerah, dan menyelenggarakan tugas umum pemerintahan. Dengan status menjadi perangkat daerah, tentu harapan akan pelayanan publik yang dekat dengan masyarakat dapat terwujud.

Kota Batam terdiri dari 12 (dua belas) kecamatan yang salah satunya adalah Kecamatan Galang. Kecamatan Galang merupakan wilayah pesisir yang memiliki tingkat kesulitan paling tinggi dibandingkan dengan kecamatan lainnya dikarenakan minimnya sarana dan prasarana ditambah lagi dengan penduduk yang tidak terkosentrasi/terpencar-pencar di beberapa pulau, sehingga untuk memajukan wilayah beserta penduduknya hingga menyamai taraf kehidupan seperti layaknya masyarakat Kecamatan lainnya terutama masyarakat yang ada di daerah perkotaan memerlukan biaya yang cukup besar juga waktu yang lama (Kecamatan Galang, 2017).

Kecamatan Galang terdiri dari Empat Kelurahan Pulau yaitu Kelurahan Karas, Subang Mas, Air Raja dan Pulau Abang. Adapun komposisi jumlah penduduk adalah sebagai berikut :

\section{Tabel 1.}

Jumlah Penduduk dan Persentasenya Menurut Kelurahan di Kecamatan Galang

\begin{tabular}{|l|c|c|}
\hline Kelurahan & Penduduk & Persentase (\%) \\
\hline Sijantung & 1.899 & 10,87 \\
\hline Karas & 2.775 & 15,89 \\
\hline Sembulang & 2.623 & 15,02 \\
\hline Subang Mas & 830 & 4,75 \\
\hline Rempang Cate & 3.79 & 21,70 \\
\hline Air Raja & 784 & 4,49 \\
\hline Pulau Abang & 1.81 & 10,36 \\
\hline Galang Baru & 2.957 & 16,93 \\
\hline Kec. Galang & 17.468 & 100,00 \\
\hline
\end{tabular}

(Sumber : Kecamatan Galang, 2017) 
Jika dilihat pada tabel diatas, Kecamatan Galang terdiri dari delapan kelurahan, dengan jumlah penduduk 17.468 jiwa, yang didominasi oleh jenis kelamin laki-laki sebanyak 9.208 orang.

Dilihat dari Ibukota kecamatan maka Kelurahan Pulau Abang merupakan wilayah terjauh dengan jarak tempuh sepanjang 48,77 $\mathrm{Km}$ dan itupun harus melalui jalur laut. Perjalanan ke Kelurahan Galang Baru jarak yang harus ditempuh sekitar 30,66 Km. Dari 8 (Delapan) kelurahan yang ada di Kecamatan Galang, hanya 4 kelurahan dapat dijangkau melalui jalur darat. Kelurahan Sembulang merupakan wilayah yang paling dekat dengan kantor kecamatan karena jaraknya kurang dari $1 \mathrm{Km}$. Sedangkan untuk ke pusat pemerintahan Kota Batam jarak tempuhnya mencapai 56,67 Km.

\section{Tabel 2.}

Nama Ibukota Kelurahan dan Jarak ke Ibukota Kecamatan Galang

\begin{tabular}{|l|l|c|}
\hline Kelurahan & $\begin{array}{l}\text { Nama Ibukota } \\
\text { Kelurahan }\end{array}$ & $\begin{array}{l}\text { Jarak Ke Ibukota } \\
\text { Kecamatan (Km) }\end{array}$ \\
\hline Sijantung & Sijantung & 28.77 \\
\hline Karas & Kampung Padang & 13.92 \\
\hline Sembulang & Sembulang & 0.5 \\
\hline Subang Mas & Subang Mas & 17.32 \\
\hline Rempang Cate & Cate & 19.00 \\
\hline Air Raja & Air Raja & 23.31 \\
\hline Pulau Abang & Pulau Abang kecil & 48.77 \\
\hline Galang Baru & Kampung Baru & 30.66 \\
\hline $\begin{array}{l}\text { Jarak Kecamatan } \\
\text { Pusat Kota }\end{array}$ & - & $\mathbf{5 6 . 6 7}$ \\
\hline
\end{tabular}

(Sumber : Kecamatan Galang, 2017)

Dengan demikian, Kecamatan Galang mempunyai tantangan tersendiri dalam memberikan pemenuhan pelayanan kepada masyarakat. Pihak Kecamatan Galang akan memiliki peran penting dalam menjangkau masyarakatnya yang berada di pulau-pulau.

Tujuan penelitian adalah untuk menganalisa upaya pelayanan administratif bagi masyarakat pulau dan kendala yang dihadapi di Kecamatan Galang Kota Batam. Penelitian ini juga berusaha untuk memberikan masukan bagi pihak Kecamatan Galang dan Pemerintah Kota Batam dalam penyelenggaraan 
pelayanan bagi masyarakat pulau. Hasil penelitian juga bermanfaat bagi penelitian yang lainnya dalam kajian pelayanan publik dengan kondisi objek penelitian yang sama. Penelitian ini dilakukan dari September 2017 sampai dengan Februari 2018.

\section{TINJAUAN PUSTAKA}

Pelayanan Publik menurut Sampara (Pratama, 2015 : 93) adalah suatu kegiatan atau urutan kegiatan yang terjadi dalam interaksi langsung antar seseorang dengan orang lain atau mesin secara fisik, dan menyediakan kepuasan pelanggan. Undang-Undang No. 25 Tahun 2009 Tentang Pelayanan Publik (pasal 1), disebutkan pengertian pelayanan publik adalah kegiatan atau rangkaian kegiatan dalam rangka pemenuhan kebutuhan pelayanan sesuai dengan peraturan perundang-undangan bagi setiap warga negara dan penduduk atas barang, jasa, dan/atau pelayanan administratif yang disediakan oleh penyelenggara pelayanan publik. Subarsono (Lodan, 2015 : 8) menyebutkan bahwa produk birokrasi publik, sebagai suatu organisasi publik, adalah pelayanan publik yang diterima oleh warga pengguna maupun masyarakat secara luas. Menurut Semil (2018 : 137) terdapat beberapa unsur yang memuaskan masyarakat yang dilayani meliputi : Keramahan Petugas, Ketepatan waktu pelayanan, Biaya Pelayanan, Kenyamanan, Kecepatan Pelayanan, Keadilan dalam Pelayanan, dan Kejelasan Petugas. Perspektif neoklasik (Jilke et all, 2016 : 421) mengatakan lebih sederhana, bahwa pelayanan publik akan menjadi lebih murah dan lebih baik, jika bertumpu pada asumsi bahwa warga memilih dari satu set penyedia layanan atau salah satu yang paling cocok dengan kebutuhan dan tuntutan mereka.

Adapun The Public Service Motivational (Jensen \& Vestergaard, 2017 : 54) mengatakan bahwa pelayanan publik harus termotivasi untuk mengeluarkan usaha lebih besar karena pekerjaan pelayanan publik memberikan opportunities untuk melakukan tugas-tugas yang bermakna dan signifikan kepada orang lain dan masyarakat, sehingga dengan begitu pelayanan publik akan menjadi lebih baik dan bisa tercapainya suatu efisiensi.

Sementara itu, Albrecht dan Zemke (Mukarom dkk, 2015 : 111) memberikan pandangan terhadap kualitas pelayanan publik yang merupakan hasil 
interaksi dari berbagai aspek, yaitu sistem pelayanan, sumber daya manusia pemberi pelayanan, dan strategi pelanggan.

Paradigma baru New Public Service yang dibangun oleh Denhardt and Denhardt menjadi suntikan dalam membangun kesadaran pelayanan publik secara khusus dan ilmu administrasi publik secara umum. Dalam pandangan NPS, lebih diarahkan pada democracy, pride and citizen daripada market, competition and customers sebagaimana yang berlaku pada sektor swasta. Pandangan NPS adalah "Public Servant do not deliver customer service, they deliver democracy" (Semil, 2018 : 86). Warga negara (the citizen) sebagai pemilik kedaulatan negara yang sah dan sebenarnya, yang harusnya mendapatkan pelayanan paripurna dari negara.

The World Bank mengambarkan bagaimana hubungan atau alur pelayanan yang diberikan oleh pemerintah kepada warganya (masyarakat) dengan menyebut pemerintah sebagai pihak yang bertanggungjawab dan masyarakat yang menerima layanan sebagai pihak yang merasakan kepuasan (Goldstein, 2008:5-7). Adapun pihak yang terlibat dalam sebuah pelayanan merupakan interaksi dari provider (penyedia layanan) dalam hal ini adalah pemerintah, Client atau Citizen dan The State (politisi dan pembuat kebijakan).

\section{METODE PENELITIAN}

Dalam penelitian ini digunakan jenis penelitian deskriptif dengan pendekatan kualitatif. Adapun fokus penelitian ini adalah upaya pelayanan administratif dan kendala yang dihadapi bagi masyarakat pulau di Kecamatan Galang. Lokasi penelitian di Kecamatan Galang Kota Batam. Alasan penentuan lokasi adalah :

1. Secara geografis memiliki tingkat kesulitan yang paling tinggi dibandingkan dengan kecamatan lainnya ditambah dengan penduduk yang tidak terkonsentrasi (terpencar-pencar) dibeberapa pulau.

2. Kecamatan terdiri dari empat kelurahan pulau dengan jarak keterjangkauan yang beragam.

3. Jarak kantor kecamatan dengan pusat pemerintahan Kota Batam yang relatif jauh $(56,67 \mathrm{Km})$. 


\section{HASIL DAN PEMBAHASAN}

Adapun penyelenggaran pelayanan administratif Kecamatan Galang meliputi administrasi kependudukan dalam menerbitkan dokumen resmi yang diterbitkan oleh instansi pelaksana yang mempunyai kekuatan hukum melaksanakan pelayanan dalam urusan penyelenggaraan kependudukan antara lain : perizinan, non perizinan dan bidang lainnya. Adapun pelayanan bidang perizinan meliputi :

1) Pemberian Tanda Daftar Usaha Pariwisata Usaha dan Jasa Makanan dan Minuman untuk Rumah Makan, Kedai Kopi, Warung dengan maksimal 50 (lima puluh) kursi ;

2) Pemberian tanda Daftar Usaha Pariwisata Usaha Daya Tarik Wisata (Salon, Pangkas, SPA dengan maksimal 5 (lima) kursi;

3) Pemberian izin gangguan Pangkalan Gas

4) Pemberian izin gangguan jual/ beli bahan bangunan;

5) Pemberian izin gangguan usaha perbengkelan klarisifikasi kecil;

6) Pemberian izin gangguan warung internet (Warnet)

7) Pemberian izin gangguan rumah makan, Catering, Kedai Kopi, Kantin, Warung, dengan maksimal 50 (lima puluh) kursi

8) Pemberian izin gangguan salon

9) Pemberian izin gangguan pangkas rambut

10) Pemberian izin gangguan Laundry

11) Pemberian izin gangguan cucian kendaraan bermotor

12) Pemberian izin gangguan tukang jahit

Sedangkan pelayanan bidang non perizinan meliputi :

1) Pemberian keterangan Domisili Usaha

2) Pengurusan KTP

3) Pengurusan Kartu Keluarga

4) Surat Pengantar Pindah

5) Surat Pengantar Pembuatan Akte Kelahiran

6) Kartu Tanda Pencari Kerja (AK1);

7) Surat Pengantar Catatan Kepolisian (SKCK) 
8) Rekomendasi Surat Izin Keramaian (Sosial)

9) Rekomendasi Suart Izin Keramaian (Komersial)

Dalam proses pelaksanaan Pelaksanaan pelayanan administratif yang ada di Kecamatan Galang ini, memiliki dasar hukumnya yaitu Peraturan Walikota Batam nomor 44 Tahun 2013 tentang Pelimpahan sebagian Wewenang Pemerintahan dari Walikota Batam kepada Camat. Dalam peraturan walikota tersebut, terdapat 12 kewenangan pelayanan bidang perizinan dan 9 pelayanan non perizinan. Selain itu, dasar hukum lainnya ialah Peraturan Daerah Kota Batam Nomor 1 Tahun 2015 Tentang Penyelenggaraan Administrasi Kependudukan di Kota Batam.

Sesuai dengan Keputusan Menteri Pendayagunaan Aparatur Nomor : 63/KEP/M.PAN/7/2003 Tentang Pedoman Umum Penyelenggaraan Pelayanan Publik, disebutkan bahwa pelayanan publik dikelompokkan menjadi tiga yaitu :

a. Pelayanan Administratif yang meliputi pelayanan yang menghasilkan berbagai bentuk surat menyurat dan dokumen resmi yang diperlukan oleh masyarakat seperti SIM, Akte Kelahiran, KTP, Akte Pernikahan dan lain sebagainya.

b. Pelayanan Barang yaitu kelompok pelayanan yang menghasilkan beragam jenis atau bentuk barang yang dibutuhkan oleh masyarakat seperti : Telepon, Listrik, Air, Jalan dan sebagainya.

c. Pelayanan Jasa yaitu kelompok pelayanan yang menghasilkan berbagai macam jenis atau entuk jasa yang diperlukan oleh masyarakat seperti pendidikan, kesehatan, transportasi, Pos dan lain sebagainya.

Pelayanan langsung kepada masyarakat yang diselenggarakan oleh Kecamatan Galang sesuai dengan Perda maupun Perwako, sebagian besar adalah pelayanan administratif dalam bentuk penyediaan dokumen resmi dan surat menyurat lainnya seperti surat rekomendasi izin keramaian, surat pengantar catatan kepolisian, pemberian izin gangguan pangkalan gas, pemberian keterangan domisili usaha, pengurusan KTP dan lain sebagainya.

Mengingat kondisi geografis Kecamatan Galang dimana terdapat empat kelurahan yang berada di pulau yaitu Kelurahan Karas, Pulau Abang, Air Raja 
dan Subang Mas, telah dilakukan beberapa upaya dalam memaksimalkan pelayanan kepada masyarakat setempat. Kondisi tersebut tentu berdampak terhadap waktu tempuh, biaya dan alat transportasi masyarakat dalam mendapatkan pelayanan, maka telah dilakukan beberapa upaya atau perlakuan khusus bagi masyarakat yang berada di 4 (Empat) kelurahan pulau tersebut. Perlakuan pelayanan secara khusus ini ditujukan untuk meringankan beban masyarakat tanpa mengurangi tertib administrasi dalam pelayanan yang diberikan. Adapun upaya tersebut meliputi :

a. Berkoordinasi dengan pihak atau pegawai kelurahan.

Dalam pelayanan administratif seperti yang dimaksud diatas, masyarakat cukup menyerahkan berkas-berkas permohonan yang diajukan kepada pihak kelurahan (pulau) sehingga nantinya akan ditindaklanjuti oleh pegawai kelurahan ke Kecamatan Galang. Kecamatan Galang memiliki agenda bulanan yaitu apel (upacara) dan rapat bersama di minggu pertama dan minggu kedua setiap bulannya untuk berkumpul di kantor kecamatan. Pada saat itulah berkas permohonan yang telah diserahkan masyarakat di masingmasing kelurahan diberikan ke bagian pelayanan umum. Pegawai masingmasing kelurahan melakukan pengecekan terhadap kelengkapan berkas yang diajukan pada saat diserahkan oleh masyarakat setempat.

b. Berkas dapat dititip di pihak penyedia atau pengemudi pompong.

Pihak kecamatan tidak keberatan apabila ada masyarakat yang menitipkan berkas pengurusannya melalui pengemudi pompong. Ada masyarakat terkadang juga menitipkan berkas permohonan yang diajukan kepada penyedia atau pengemudi pompong (alat transportasi laut tradisional), jika memang tidak mau menunggu melalui pihak kelurahan. Jika menyerahkan kepada pihak kelurahan, maka sebagaimana yang telah dijelaskan sebelumnya, berkas akan diserahkan pada minggu pertama dan kedua setiap bulannya. Penyedia atau pengemudi pompong yang nantinya akan menghubungi pegawai Kecamatan Galang jika ada titipan permohonan berkas. Pegawai kecamatan yang akan mengambil berkas tersebut di pelabuhan yang jaraknya tidak terlalu jauh dari Kantor Kecamatan Galang. 
Perlu juga diketahui, jadwal perjalanan pompong atau perahu khusus penumpang tersebut hanya sekali pulang-pergi setiap harinya.

c. Tersedianya rumah dinas pegawai di komplek Kantor Kecamatan.

Hal yang tidak biasanya juga terlihat ketika mengunjungi Kantor Kecamatan Galang, di sekeliling komplek kantor terdapat rumah-rumah dinas pegawai. Rumah dinas tersebut diperuntukkan bagi pegawai yang bersedia untuk tinggal dikarenakan banyak juga pegawai yang tinggal di daerah pusat Kota Batam dan sekitarnya. Rumas dinas ini selain sebagai rumah tinggal tetapi juga sebagai tempat masyarakat dapat menyerahkan berkas pengajuan permohonan diluar jam pelayanan yang ada. Rumah dinas ini juga digunakan untuk memberikan kemudahan bagi pegawai dalam menjalankan tugas mengingat kondisi Kecamatan Galang yang jauh dari pusat kota atau tempat tinggal pegawai sebenarnya. Salah satu pegawai yang telah tinggal di rumah dinas tersebut dalam jangka waktu yang cukup lama ialah Ibu Herli Yusdina (Staf Pelayanan Umum). Kelengkapan syarat-syarat pun tetap diperiksa terlebih dahulu baru keesokan harinya diproses.

d. Upacara bersama dan Rapat setiap awal bulan

Kecamatan Galang memiliki agenda bulanan yaitu upacara bersama dan rapat setiap awal bulan. Dimana pegawai-pegawai kelurahan berkumpul untuk mengikuti agenda tersebut pada minggu pertama dan kedua. Disaat bersamaan pihak kelurahan membawa berkas permohonan yang telah dititipkan oleh masyarakat setempat. Memang jika dilihat, kondisi ruangan pelayanan tampak sepi atau tidak terlalu ramai dari aktivitas masyarakat yang akan mengurus dokumen seperti yang terjadi di beberapa kecamatan seperti Batam Kota, Sagulung, Batu Aji. Kesibukan pengurusan dokumen atau berkas yang diajukan baru terlihat pada minggu pertama dan kedua setiap bulannya. Namun yang terlihat banyak atau ramai ialah dokumen atau berkas tanpa terlihat masyarakat yang secara langsung mengurus sendiri. Dengan adanya agenda ini, menjadi wadah untuk berkoordinasi atau membangun sinergitas antara Kecamatan Galang dan kelurahan yang ada. Peningkatan pemahaman masyarakat mengenai informasi pelayanan administratif dapat 
dilakukan oleh pihak kelurahan sebagai kepanjangan tangan pelayanan dari Kecamatan Galang.

\section{e. Sosialisasi}

Pihak kecamatan juga telah melakukan sosialisasi kepada masyarakat yang ada di 8 (delapan) kelurahan. Kegiatan ini bertujuan meningkatkan pemahaman masyarakat mengenai informasi segala macam jenis layanan dan aturan baru yang ada. Kegiatan ini dilakukan setahun 2 (dua). Dalam pelaksanaan sosialisasi, pihak kecamatan juga difasilitasi oleh pegawai kelurahan setempat yang merupakan penduduk daerah tersebut untuk dapat membantu memperlancar dalam proses berkomunikasi. Mengingat sebagaian besar penduduk di pulau-pulau tersebut menggunakan bahasa Melayu sebagai bahasa sehari-hari. Tidak hanya itu, hal ini juga untuk mengurangi ketidakpahaman masyarakat terhadap aturan, prosedur atau syarat-syarat yang wajib dipenuhi sehingga dapat dengan mudah dipersiapkan dan difasilitasi jika ada kendala.

Perlu diketahui, bahwa tidak semua jenis layanan administratif tersebut dapat diwakilkan kepada pihak kelurahan setempat atau penyedia pompong. Jenis pelayanan seperti perekaman E-KTP, semua masyarakat diwajibkan untuk melakukan pengurusan sendiri. Dalam konteks ini, Subarsono mengemukakan bahwa produk suatu organisasi publik, adalah pelayanan publik yang diterima oleh warga pengguna maupun masyarakat secara luas (Lodan, 2015 : 8). Upaya yang dijalankan oleh Kecamatan Galang dengan situasi yang dihadapi merupakan sebuah produk dari instansi pemerintah yang menghasilkan berbagai macam bentuk atau terobosan pelayanan yang dapat diterima atau dirasakan manfaatnya oleh masyarakat setempat. Penulis meyakini bahwa aparatur Kecamatan Galang memberikan ruang bagi masyarakat dalam berpartisipasi menciptakan pelayanan yang dapat diterima secara bersama antara penyedia (kecamatan) dan penerima layanan (masyarakat).

Hal ini senada dengan perspektif New Public Service (NPS) yang dikemukakan oleh Denhardt and Denhardt. Dalam pandangan NPS, lebih diarahkan pada democracy, pride and citizen daripada market, competition and 
customers sebagaimana yang berlaku pada sektor swasta. Pandangan NPS adalah "Public Servant do not deliver customer service, they deliver democracy" (Semil, $2018: 86)$.

Pelanggan merupakan sebutan bagi penerima layanan yang telah disediakan oleh penyedia layanan dalam organisasi bisnis. Organisasi bisnis lebih menekankan pada aspek untung rugi secara ekonomi sedangkan NPS memperlakukan masyarakat sebagai warga negara sebagai empunya negara sehingga perlu dilayani tanpa memandang aspek untung rugi. Kompetisi dalam organisasi bisnis lebih didasarkan pada kemampuan masyarakat secara ekonomi untuk mendapatkan pelayanan yang disediakan. Masyarakat yang memiliki kemampuan secara ekonomi lebih memiliki peluang yang besar untuk memperoleh pelayanan dan sebagai pelanggan prioritas. Sedangan NPS meletakkan pelayanan sebagai kepentingan publik yang dapat dirasakan oleh semua warga tanpa melihat status ekonomi. Organisasi bisnis meletakkan penggunaan pelayanan kepada mekanisme pasar, adanya transaksi "jual-beli" layanan. Masyarakat dapat memilih jenis layanan sesuai dengan "harga" layanan yang disediakan. Sedangkan NPS meletakkan penggunaan layanan pada aspek demokrasi dengan adanya ruang bagi masyarakat untuk berpartisipasi dalam menciptakan layanan yang bermanfaat dan diterima secara luas.

Oleh karena itu, nilai penting yang menjadi dasar dalam pandangan ini ialah demokrasi, kepentingan publik dan kewarganegaraan. Pelayanan administratif yang diselenggarakan oleh Kecamatan Galang bukanlah layaknya sebuah organisasi bisnis tetapi mendasarkan pada nilai-nilai demokrasi dan kepentingan publik. Konsekuensi dari hal tersebut, aparatur kecamatan harus terus belajar akan terobosan maupun keahlian baru yang dapat menunjang pelayanan itu sendiri. Aparatur kecamatan (termasuk kelurahan) juga harus memahami tugas dan tanggungjawab yang harus mereka lewati dalam memposisikan masyarakat sebagai warga negara yang memiliki rasa hormat dan harga diri. Aparatur harus banyak merespon dan melayani daripada harus mengendalikan masyarakat. Aparatur dan masyarakat sebagai warga negara harus bisa bekerja sama mendiskusikan berbagai masalah dan mencari solusi yang dapat mendorong 
percepatan pelayanan. Dalam konteks ini, kondisi demikian yang sering diungkap oleh Denhardt sebagai perilaku dan keterlibatan baru dalam pergerakan administrasi publik yang disebut sebagai The New Public Service. Inti dari The New Public Service ialah pelayanan publik bukan hanya berfokus pada memberi kepuasan kepada pelanggan, melainkan mendorong terciptanya kolaborasi dan kepercayaan antara pemerintah dan warga. Selain itu, hal senada juga disampaikan Jilke et all (2016 : 421). Perspektif neoklasik memberikan pandangan yang lebih sederhana bahwa pelayanan publik akan menjadi lebih murah dan lebih baik, jika bertumpu pada asumsi bahwa warga memilih dari satu set penyedia layanan atau salah satu yang paling cocok dengan kebutuhan dan tuntutan mereka. Dengan kondisi geografis yang ada, tentu masyarakat akan memilih rangkaian pelayanan yang mudah dijangkau dan menghemat waktu dengan memanfaatkan keberadaan kantor kelurahan. Hal ini tentunya akan berdampak pada murahnya biaya yang harus dikeluarkan dan menyita waktu yang terlalu lama dalam menjangkau lokasi pelayanan. Adapun Jensen \& Vestergaard (2017 : 54) mengatakan bahwa pelayanan publik harus termotivasi untuk mengeluarkan usaha lebih besar karena pekerjaan pelayanan publik memberikan opportunities untuk melakukan tugas-tugas yang bermakna dan signifikan kepada orang lain dan masyarakat, sehingga dengan begitu pelayanan publik akan menjadi lebih baik dan bisa tercapainya suatu efisiensi.

Sementara itu dalam pandangan Albrecht dan Zemke (Mukarom dkk, 2015 : 111), kualitas pelayanan publik yang merupakan hasil interaksi dari berbagai aspek, yaitu sistem pelayanan, sumber daya manusia pemberi pelayanan, dan strategi pelanggan. Pandangan ini menunjukkan bahwa semangat mewujudkan kualitas pelayanan publik tidak bisa diserahkan kepada salah satu dari ketiga aspek, tetapi harus didukung oleh aspek lainnya yang saling memiliki hubungan keterkaitan. Ketiga aspek tersebut harus memiliki hubungan yang selaras dan saling mendukung. Sistem pelayanan yang meliputi persyaratan, prosedur, waktu, biaya dan lain sebagainya, tidak ada artinya jika tidak dibarengi oleh kemampuan petugas dalam menyelesaikan setiap urusan pelayanan sesuai dengan waktunya atau petugas yang bertele-tele dalam menyelesaikan urusan 
pelayanan karena tidak diberi imbalan. Namun jika system pelayanan dan sumber daya manusia pemberi layanan saling mendukung, tetapi tidak pula dibarengi dengan strategi pelanggan menyebabkan pemberian pelayanan kepada masyarakat menjadi biasa-biasa saja tidak memiliki nilai inovatif. Artinya aparatur kecamatan juga diminta untuk melakukan serangkaian upaya yang dapat memaksimalkan pelayanan kepada masyarakat dalam bentuk berbagai terobosan seperti yang telah dilakukan oleh Kecamatan Galang.

Namun pandangan Albrecht dan Zemke tersebut tidak sejalan dengan perspektif New Public Service oleh Denhardt dalam menempatkan posisi masyarakat. Albrecht dan Zemke lebih menempatkan masyarakat sebagai pelanggan. Kecamatan sebagai organiasi publik yang tidak berorientasi profit oriented, tentu lebih sangat cocok ditinjau dari perspektif NPS. Namun dengan alasan peninjauan hubungan antar aspek yang saling mempengaruhi dalam meningkatkan kualitas pelayanan publik termasuk di Kecamatan Galang, maka pandangan tersebut dapat memperkaya pemahaman para aparatur.

Berbeda dengan Albrecht dan Zemke yang lebih menekankan pada hubungan atau interaksi antar unsur, The World Bank memberikan gambaran tentang hubungan antara pihak yang terlibat dalam pelayanan publik. The World Bank mengambarkan bagaimana hubungan atau alur pelayanan yang diberikan oleh pemerintah kepada warganya (masyarakat) dengan menyebut pemerintah sebagai pihak yang bertanggungjawab dan masyarakat yang menerima layanan sebagai pihak yang merasakan kepuasan (Goldstein, 2008 : 5-7). Adapun pihak yang terlibat dalam sebuah pelayanan merupakan interaksi dari provider (penyedia layanan) dalam hal ini adalah pemerintah, Client atau Citizen dan The State (Politisi dan Pembuat kebijakan). Pemerintah dalam hal ini adalah Kecamatan Galang memiliki tanggungjawab dalam menyediakan pelayanan administratif sekalipun dengan kondisi geografis yang terdiri dari beberapa pulau. Oleh karena itu, Kecamatan Galang perlu mendengar dan merespon tuntutan masyarakat akan pelayanan yang diinginkan dengan melahirkan konsep atau terobosan yang bermanfaat. Tidak hanya itu, para politisi atau pembuat kebijakan yaitu Walikota dan DPRD Kota Batam perlu melakukan monitoring terhadap pelaksanaan 
pelayanan tersebut sehingga dapat melahirkan kebijakan-kebijakan pelayanan yang bisa dirasakan manfaatnya oleh masyarakat ketika diimplementasikan.

Dari hasil penelitian yang telah dilakukan dengan melakukan beberapa konfirmasi melalui wawancara, ditemukan beberapa kendala yang dihadapi dalam proses penyelenggaran pelayanan administratif. Berikut adalah beberapa kendala yang dihadapi :

a. Listrik

Kecamatan Galang baru 6 (enam) bulan (September 2017-Februari 2018) ini dapat menggunakan listrik dari PLN. Sebelumnya menggunakan genset dalam melakukan operasional tugas sehari-hari. Tidak hanya itu juga, pemadaman listrik juga sangat mempengaruhi pelayanan karena akan mengurangi kecepatan waktu pelayanan. Dalam menunjang proses pelayanan kepada masyarakat, dukungan daya dan kestabilan listrik juga sangat mempengaruhi.

b. Internet

Dengan berbagai kebutuhan penginputan data menggunakan sistem online, jaringan internet merupakan kebutuhan yang tidak bisa dihindari, apalagi bagi instansi pemerintah. Kebutuhan jaringan internet dibutuhkan untuk memudahkan penginputan data atau pengiriman data antar instansi dan mempercepat proses pelayanan. Pada tahun 2015 jaringan internet itu telah ada, namun jaringannya tidak maksimal sehingga dicabut oleh pihak penyedia (CV). Baru awal tahun 2018, jaringan internet telah bisa digunakan kembali dengan tingkat penggunaan yang lebih maksimal. Selama ini penginputan data layanan dilakukan diluar kantor dengan membawa laptop dan membeli kuota internet.

c. Pemahaman masyarakat

Masyarakat banyak mengeluhkan soal syarat-syarat yang harus dilengkapi, khususnya masyarakat yang ada di pulau. Hal ini dikarenakan belum pahamnya masyarakat terhadap syarat atau prosedur pengajuan permohonan yang telah ditentukan. Sehingga masyarakat beranggapan syarat atau prosedur tersebut membuat susah dan membingungkan. Oleh 
karena itu diperlukan kepanjangan tangan dari pihak kelurahan untuk dapat membantu masyarakat yang berada di 4 (empat) pulau dalam memahami syarat-syarat maupun prosedur pelayanan yang ada.

d. Alat perekam E-KTP yang rusak

Selanjutnya yang dikeluhkan masyarakat lagi adalah karena harus melakukan perekaman e-KTP ke Kecamatan Batu Aji dikarenakan alat perekam sementara ini rusak sejak akhir tahun 2017. Untuk beberapa bulan terakhir ini, alat perekaman E-KTP rusak sehingga membuat masyarakat harus mengurus perekaman ke kecamatan lain. Tentu kondisi ini membuat masyarakat terbebani karena harus menempuh jarak yang lumayan jauh lagi, padahal untuk menuju Kecamatan Galang sendiri mereka sudah merasakan waktu tempuh yang jauh juga.

Semil (2018 : 137) menyebutkan beberapa unsur yang memuaskan masyarakat yang dilayani meliputi : keramahan petugas, ketepatan waktu pelayanan, biaya pelayanan, kenyamanan, kecepatan pelayanan, keadilan dalam pelayanan, dan kejelasan petugas. Kepuasan masyarakat terhadap sebuah penyelenggaraan pelayanan menunjukkan adanya manfaat yang dapat dirasakan. Kendala yang dihadapi Kecamatan Galang tentunya akan berdampak pada proses pelayanan dan mengakibatkan rendahnya tingkat kepuasan masyarakat. Kendala yang dihadapi oleh Kecamatan Galang dikelompokkan menjadi dua yaitu menyangkut aspek sarana dan prasarana serta pemahaman masyarakat. Sarana dan prasarana, menyangkut unsur kenyamanan serta kecepatan pelayanan. Tersedianya aliran listrik, dan jaringan internet yang memadai serta ketersediaan alat perekam E-KTP, tentu akan memberikan daya dukung terhadap kecepatan proses pelayanan sehingga memberikan kenyamanan dalam memanfaatkan waktu penyelesaian proses layanan.

Sedangkan pemahaman masyarakat menyangkut pada unsur keadilan pelayanan dan kejelasan petugas. Unsur keadilan dalam pelayanan artinya aparatur Kecamatan Galang harus memberikan perlakuan yang sama pada semua unsur atau golongan masyarakat yang dilayani tanpa membedakan status baik secara sosial, ekonomi dan politik. Perlakuan yang sama juga dimaksudkan dalam 
memberikan informasi terkait sistem pelayanan kepada masyarakat yang berada di pulau, sekalipun berbeda tingkat pemahamannya jika dibandingkan pada masyarakat yang berada dekat dengan pusat kota. Unsur kejelasan petugas berkaitan dengan siapa, bertugas dan bertanggungjawab apa dan pegawai yang sedang bertugas. Kejelasan petugas ini tentu akan sangat membantu kendala Kecamatan Galang dalam meningkatkan pemahaman masyarakat akan sistem pelayanan yang ada. Artinya aparatur kecamatan dan kelurahan mempunyai tugas dan tanggungjawab yang sama dalam mendistribusikan informasi serta membantu menterjemahkannya dalam bahasa sehari-hari sehingga mudah dipahami. Tentu hal ini juga dapat memberikan kepuasan kepada masyarakat. Penguasaan informasi terkait sistem layanan dan metode penyampaiannya harus dimiliki oleh semua aparatur atau yang diberikan tanggungjawab untuk menangani hal tersebut. Menurut Saragih (Jafar, 2009:87), pelayanan publik merupakan unsur paling penting dalam meningkatkan kualitas hidup sosial di dalam masyarakat manapun.

\section{KESIMPULAN}

1. Dalam memberikan pelayanan administratif kepada masyarakat pulau di Kecamatan Galang Kota Batam, telah dilakukan beberapa upaya. Upaya tersebut menunjukkan komitmen aparatur Kecamatan Galang dalam menyediakan pelayanan yang sesuai dengan kebutuhan dan manfaat yang dapat dirasakan oleh masyarakat. Upaya tersebut juga menunjukkan adanya perlakuan nilai-nilai demokrasi dalam menciptakan usaha pelayanan secara bersama.

2. Kendala dalam pelayanan administrasi seperti fasilitas sangat memberikan pengaruh terhadap proses pelayanan kepada masyarakat. Hal ini berdampak pada kenyamanan dan kecepatan pelayanan. Sarana dan prasarana merupakan salah satu unsur yang memiliki pengaruh dalam mengukur kepuasan masyarakat. Rendahnya pemahaman masyarakat terhadap sistem layanan menjadi tanggungjawab aparatur untuk menterjemahkannya sehingga mudah dipahami. 


\section{DAFTAR PUSTAKA}

Goldstein, M. (2008). Why Measure Service Deliver? Dalam Are You Being Serve?: New Tools for Measuring Service Delivery. Washington: The World Bank.

Jafar, R. A. (2009). Kualitas Pelayanan Publik setelah Perubahan Kedudukan dan Fungsi Camat sebagai Perangkat Daerah. Bisnis Dan Birokrasi, Jurnal Ilmu Administrasi Dan Organisasi 16 (2) 87-95.

Jensen, U. T., \& Vestergaard, C. F. (2017). Public service motivation and public service behaviors: Testing the moderating effect of tenure. Journal of Public Administration Research and Theory 27(1): 52-67.

Jilke, S., \& et all. (2016). Responses to Decline in Marketized Public Services: An Experimental Evaluation of Choice Overload. Journal of Public Administration Research and Theory 26(3): 421-432.

Lodan, K. T. (2015). Peran Strategis Kecamatan dalam Pelayanan Publik (Studi di Kecamatan Sagulung Kota Batam). Sosial Dan Humaniora 1(2): 1-11.

Mukarom, Z., \& dkk. (2015). Manajemen Pelayanan Publik. Bandung: CV Pustaka Setia.

Pratama, H. (2015). Strategi Meningkatkan Kualitas Pelayanan Publik (Studi Deskriptif tentang Strategi UPTD Pengujian Kendaraan Bermotor Tandes Kota Surabaya dalam Meningkatkan Kualitas Pelayanan Pengujian Kendaraan Bermotor). Kebijakan Dan Manajemen Publik 3(3), 90-98.

Semil, N. (2018). Pelayanan Prima Instansi Pemerintah. Depok: PRENADAMEDIA GROUP.

Sugiyono. (2016). Metode Penelitian Kuantitatif, Kualitatif, dan R\&D. Bandung: Alfabeta.

Peraturan Walikota Batam Nomor 44 Tahun 2013 tentang Pelimpahan sebagian Wewenang Pemerintahan dari Walikota Batam kepada Camat

Peraturan Daerah Kota Batam Nomor 1 Tahun 2015 Tentang Penyelenggaraan Administrasi Kependudukan di Kota Batam 